\section{CIHM} Microfiche Series (Monographs)
ICMH

Collection de microfiches (monographies)
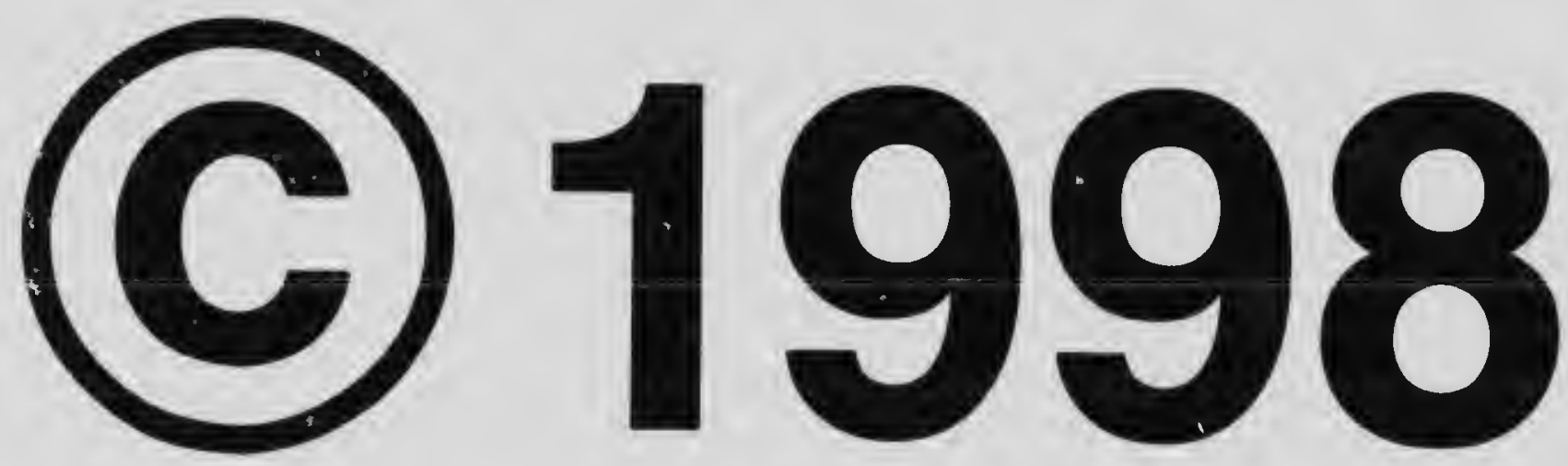


\section{Technical and Bibliographic Notes / Notes techniques et bibliographiques}

The Institute has attempted to obtain the best original copy available for filming. Feature's of this copy which may be bibliographically unique, which may alter any of the images in the reproduction, or which may significantly change the usual method of filming are checked below.

Coloured covers /

Couverture de couleur

Covers damaged /

Couverture endommagée

Covers restored and/or laminated /

Couverture restaurée eVou pelliculée

Cover title missing / Le titre de couverture manque

Coloured maps / Cartes géographiques en couleur

Coloured ink (i.e. other than blue or black) /

Encre de couleur (i.e. autre que bleue ou noire)

Coloured plates and/or illustrations /

Planches etou illustrations en couleur

Bound with other material /

Relié avec d'autres documents

Only edition available /

Seule édition disponible

Tight binding may cause shadows or distortion along interior margin / La reliure serrée peut causer de l'ombre ou de la distorsion le long de la marge intérieure.

Blank leaves added during restorations may appear within the text. Whenever possible, these have been omitted from filming / II se peut que certaines pages blanches ajoutées lors d'une restauration apparaissent dans le texte, mais, lorsque cela était possible, ces pages n'ont pas été filmées.
L'Institut a microfilmé le meilleur exemplaire qu'il lui a été possible de se procurer. Les détails de cet exemplaire qui sont peut-être uniques du point de vue bibliographique, qui peuvent modifier une image reproduite, ou qui peuvent exiger une modification dans la méthode normale de filmage sont indiqués ci-dessous.

Coloured pajes / Pages de couleur

Pages damaged / Pages endommagées

Pages restored and/or laminated /

Pages restaurées eVou pelliculées

Pages discoloured, stained or foxed/

Pages décolorées, tachetées ou piquées

Pages detached / Pages détachées

\section{Showthrough / Transparence}

Quality of print varies /

Qualité inégale de l'impression

Includes supplementary material /

Comprend du matériel supplémentaire

Pages wholly or partially ubscured by errata slips, tissues, etc., have been refilmed to ensure the best possible image / Les pages totalement ou partiellement obscurcies par un feuillet d'errata, une pelure, etc., ont été filmées à nouveau de laçon à obtenir la meilleure image possible.

Opposing pages with varying colouration or discolourations are filmed twice to ensure the best possible image / Les pages s'opposant ayant des colorations variables ou des décolorations sont tilmées deux fois afin d'obtenir la meilleure image. possible.

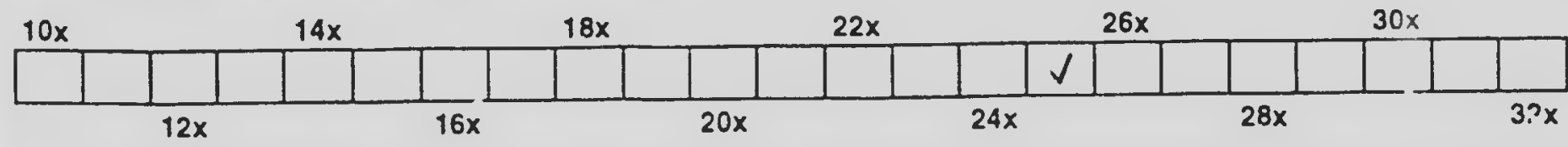


The copy filmed hara hes been raproduced thanks to the genarosity of:

$$
\text { National Library of Canada }
$$

The imeges appearing hare are the bast quality possible considaring the condition and lagibillty of the original copy and in keeping with the filming contract apecificetiona.

Original copies in printed papar covars are fllmod baginning with the front cover and endlng on the last page with a prlntad or illustrated impression. or tha back covar when appropriata. All other original copias are filmad beginning on the first page with a printed or illustrated impression. and andling on the last paga with a printed or illustratad imprassion.

Tha last racordad frame on aech microfich shall contain the symbol $\longrightarrow$ Imaening "CON. TINUED"), or the symbol $\nabla$ (maening "END"), whichavar applies.

Maps, plates, charts, atc.. may be filmad at difforant reduction ratios. Those too larga to be entiraly includad in one axposura are filmad baginning in the uppar latt hand cornar, late to right and top to bottom, as many framas as required. The following diagrams illustrate the mothod:
L'axemplaire filmó fut raproduit gráce to gondrosité de:

\author{
Bibliothèque nationale du Canada
}

Las imagas suivantes ont dt' reproduites avac le plus grand soin. compre tanu da la condition et da la nattaté da l'axamplaira filmb. at an conformith avec las conditions du contrat de fllmage.

Lee axamplairas originaux dont la couverture en papiar ast imprimbe sont filmbs an commençant par la promiar plat at an terminant soit par la darnidrs page qui comporta une empreinte d'impression ou d'illustration. soit par la second plat, salon lo cas. Tous las autras axamplairas originaux sont filmbs on commancant par la pramidra page qui comporta une ampreinte d'imprassion ou d'illustration at an terminant uar la dernidre page qui comporte une telle emprainta.

Un des symboles suivants apparaitra sup la dernidre imaga de chaque microfiche. selon le ces: le symbole $\longrightarrow$ signifie "A SUIVRE", le symbole $\nabla$ signifia "FIN".

Las cartes. planchas. tableaux, atc., pouvent ètre filmbs das toux de róduction différants. Lorsqua la documant ast trop grand pour atre roproduit an un saul clichd, il est filmé à partir de l'angle supérieur gauche, de gauche a droite. ot da haut an bas. on prenant le nombre d'images ndcessaire. Les diagrammes suivants illustrant la mothoda.
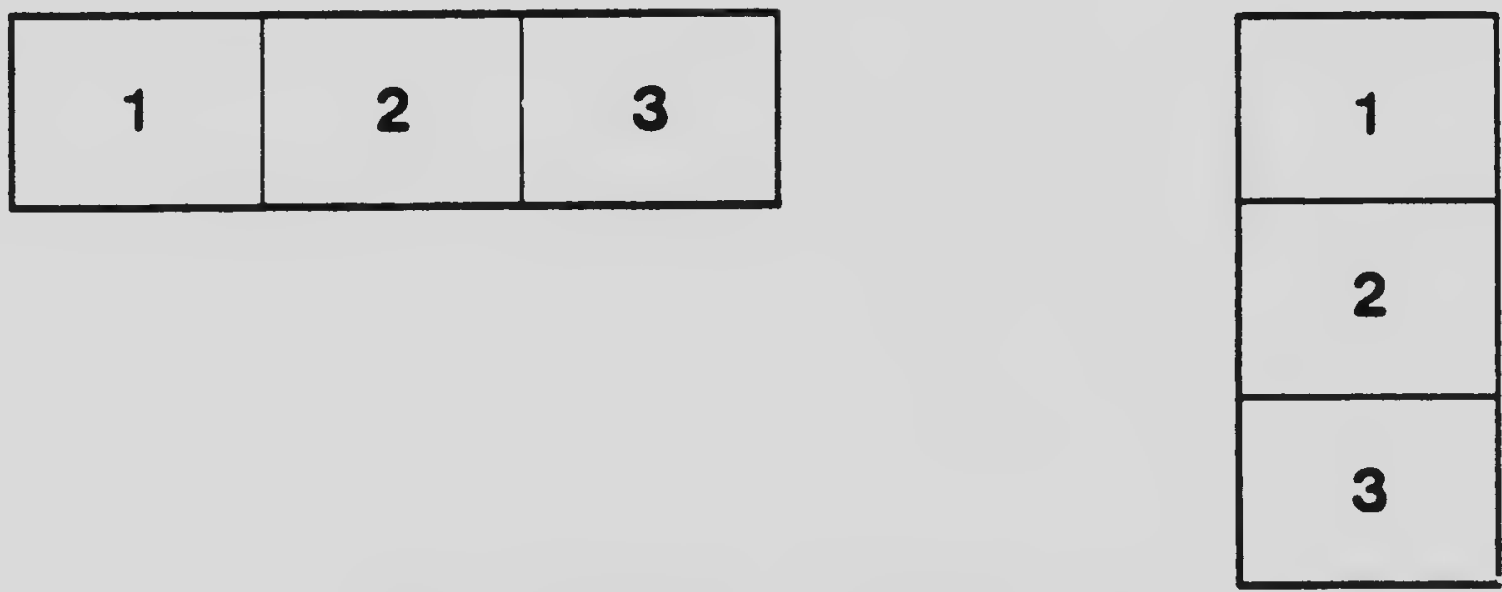

\begin{tabular}{|l|l|l|}
\hline 1 & 2 & 3 \\
\hline 4 & 5 & 6 \\
\hline
\end{tabular}


MICROCOPY RESOLUTION TEST CHART

(ANSI and ISO TEST CHART No 2

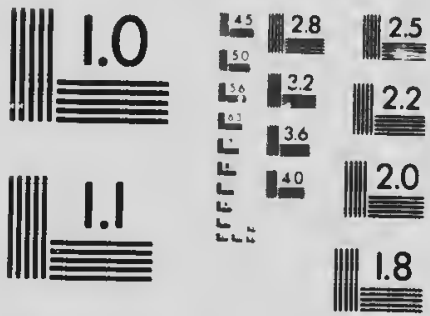

||||||||.25

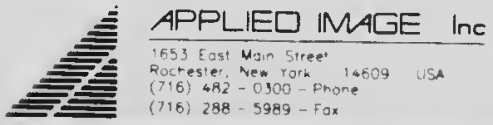




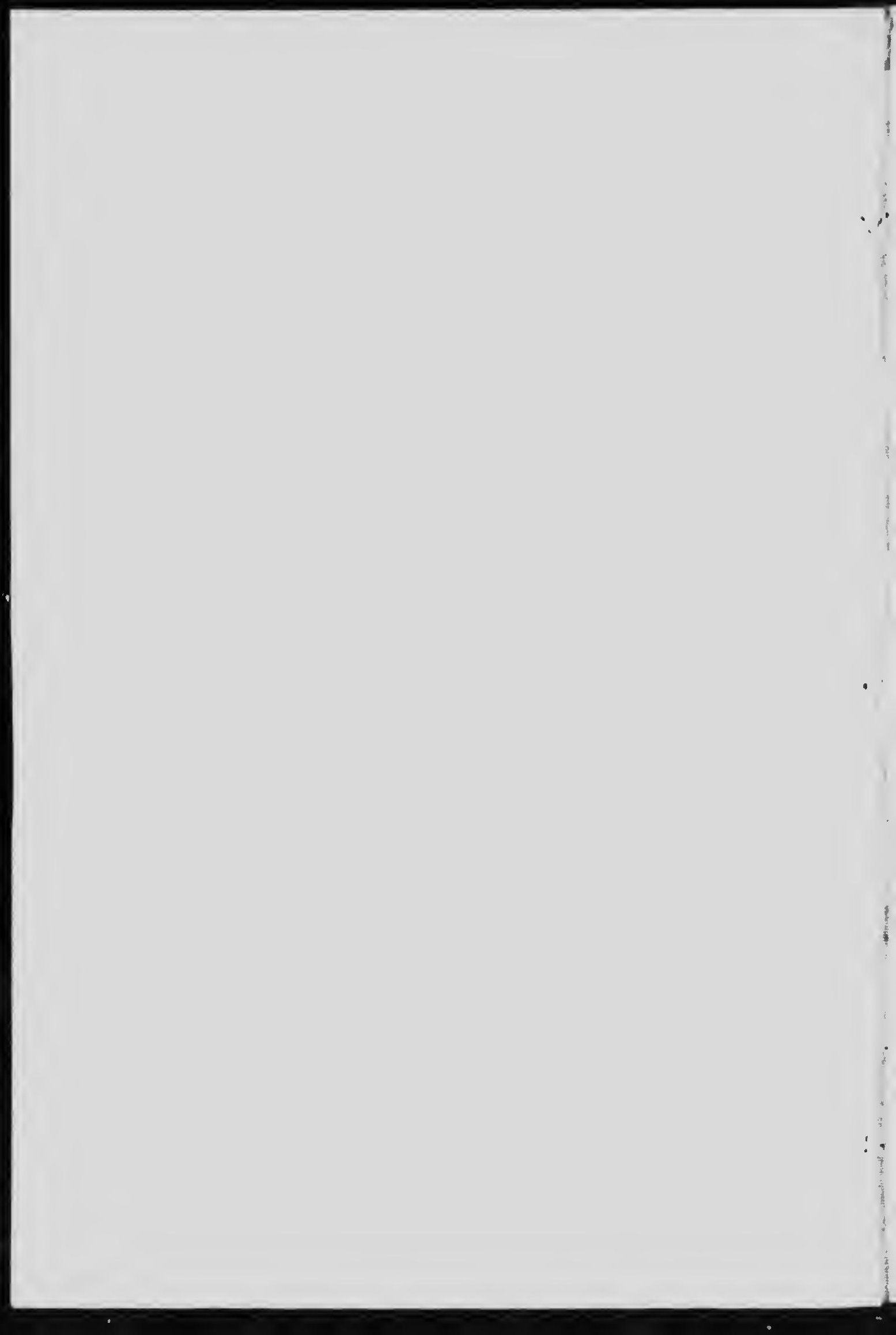




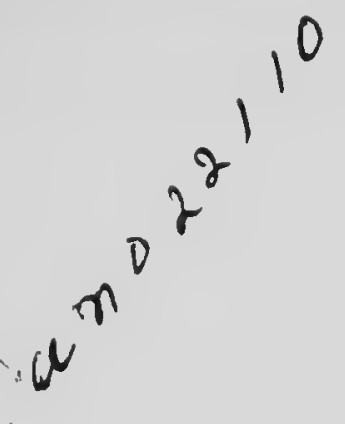

\title{
BIRD-HOUSES AND THEIR OCCUPANTS
}

\author{
BY P. A. TAVEkner
}

Reprinted from The Ottawa Naturalist, Vol, XXXII, January, 1919. (DATE of Issue, March 6Th, 1919). 

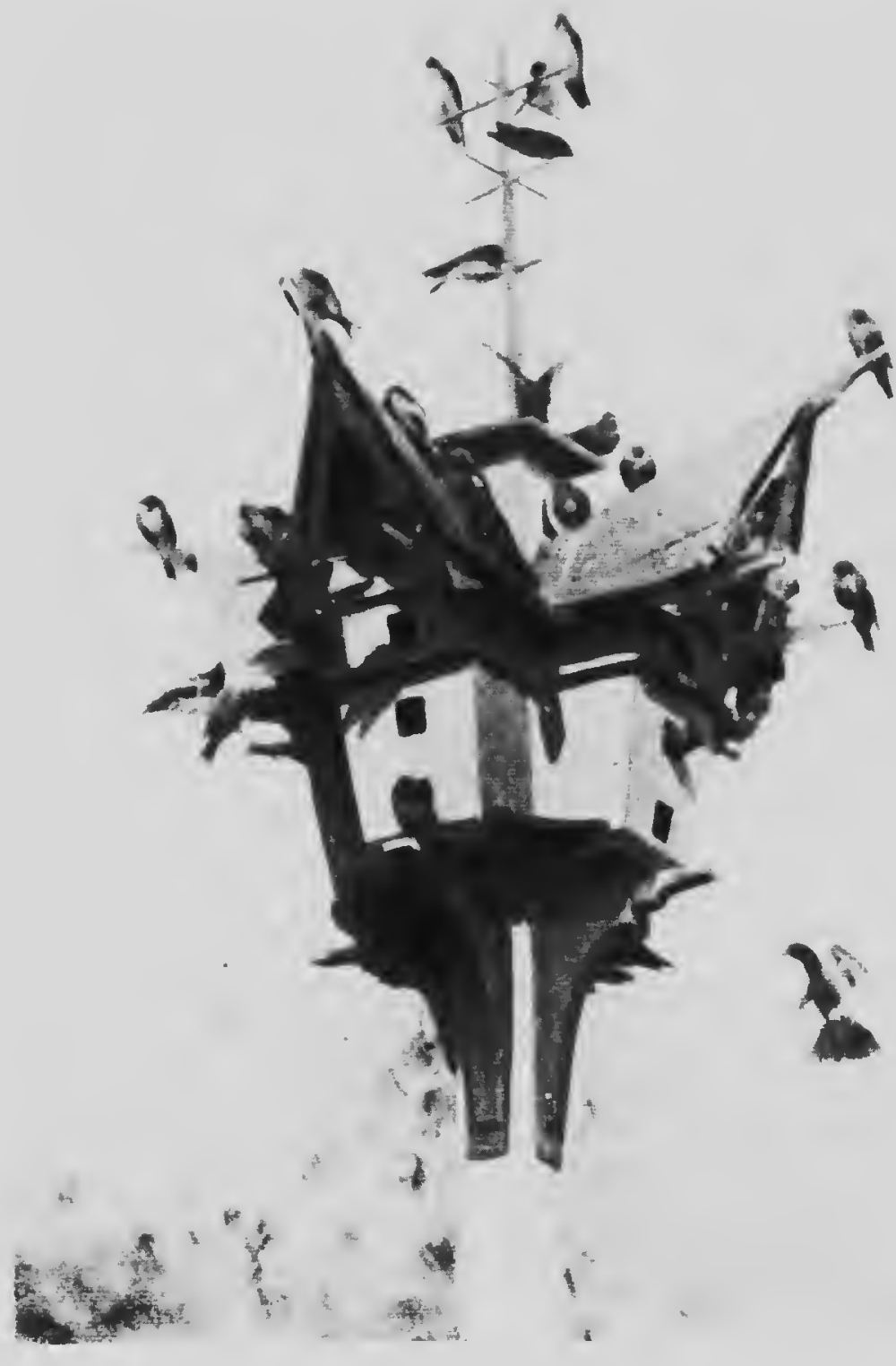

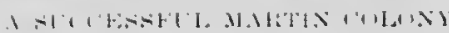




\section{THE OTTAWA NATURALIST}

\section{BIRD-HOUSI:S AND THFIR OCCUPANTS**}

\section{By P. A. Talernek.}

Like De:d mona, we "have a divided duty". On the one hand to cultivatc the land cleanly, and on the other, to attract birds to it. These are opposed duties. If we cut the dead wood from our wood lots, parks, and groves; elean out, sterilize, and fi!l rotting spots in limb and trunk with concrete, we deprive many birds of nesting facilities. If we clear out tangled brush, cultivate to the fence lines, open the ground about young, second-growth plantations, and drain the last marshy spots, we deprive many of necessary cover and the food that gocs with it Insect, weed, and small maminal pests may be reduced; but so, inevitably, will the birds as well. The consequence is likely to be that, whilst our control of pests on the whole will be better, we shall be subject to occasional sporadic outbursls of species that are not subject to these particular methods of control. Whilst the study of their food habits may suggest that birds do not usually partake largely of those insects (for example, the potato bug) whose numbers commonly assume plague proportions, it is also evident that insects that birds systematically ferd upon, rarely become plagues. We kıow, to our sorrow, the few instances where our conirol is inadequate, but we have no means of knowing the innumerable cases where it has warded off disaster.

The real value of birds as guardians of cur ficlds and gardens is not in the individual species but in the aggregate, each filling its own narrow field, yet all combined, covering crery weak point. The swallow: hawk through the upper air; the vircos, orioles, and tanagers haunt the tree tops; the weod. peckers and chickadecs, the limbs and bark crevices; whilst thrushes cxamine the dabris of wocded grounds and the sparrows and meadow larks scour open fields and shrubbery tangles. In faet at no perica of their life cycles are insects free from avian att $z=\mathbf{k}$-flying, creeping, liding or buried in the ground or in solid wood - there are specics of birds fitted for and eager to attack them. Should any one class of thcse, our unpaid assistants, be prevented from functioning, an opening is le $\mathrm{ft}$ in our defence that may be an Achilles' heel to our un. doing. If we turn our woods into groves, meadows into lawns, and tangles into formal shrubbery something of this sort is possible, unless compensations are provided. In the honse grounds and eity streets and parks the idcal of clean cultivation is most nearly approached and here it is the more necessary to provide artificially the necessities of bird life that are missing.

Bird boxcs will largely compensate for natural cavities in trees and carefully selected piantings of shrubbery and decorative flowers in naturalistic design will supply cover and fruit and seed food. If we fortunatcly succeed in reducing insects to a point dangerous to bird welfare the deficiency can be supplied by scraps of animal matter presented at fecding stations, on shelves, or in shelters. In thcse ways only can we partially compensate for our interference with the natural scheme and retain wild birds under conditions of high cultivation. Incidentally, as the home lot is the first to be made atractive to birds, we draw their interesting personalities close about us, and in place of having to tramp miles to their secluded haunts, decoy them to our very windows where they can be enjoyed practically continuously instead of occasionally, intimately instead of distantly, and at ease instead of by exertion. Any one of the methods above suggested requires, for intelligent development, a paper to itsclf; and the first, only, the building of bird l:ouses and boxes, will be here discussed.

The first thing to consider in building a bird box is the species for which it is designed. Each has its own requirements and though its necessities are more or less lastic the more nearly we fulfil the bird's ideal the morc successful we shall be in getting it to use what we provide. In short we must cater to the customs and idiosyncrasies of our tenants and not to our own ideas of convenience and beauty. It

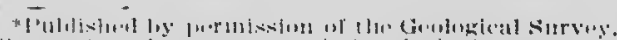

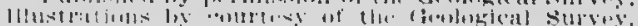


In only after the former hawe heen fully met that we call indulge the latter. The dore mot necesanty Imean thast laste and ingenutly in the designer is all rbjectomit, hut only that the fundamentas rules of art geveren bild houa bulding in well as more srious architecture that the structure must first be adnpled to it intended uae and thit beauty that intrefferes with this use is false art and bad architeeture. A slungled cottage built to lcok like a medacial castle is bod iaste, and a hired heuse in too close inulation of a cily hall, i wid ty the camons of pure art, is equally questionable. Artistically, the most successful bird house is the one, which, while fultilling the practical hird requre. ments, relains pleising lines and agreeable surfaces hut louks frankly what it is a house for hirds and not a toy human habitation.

\section{TIIF. PL'RI'L. MARTIV.}

Probably the bird mest generally welconic d about the hone is the Puiple Martin. This is our largest swallow, comparable in aies to the omnipresent, Fnglish, or, as it is more correctly named, flouse Sparrow. In colour. We adult male is all black with steely and purple reflections that give the species its llanse. 'The female and young male are aluevel black above with slight indications of iridesscence, dull or dirty grey below, alnost whic on th. abdone'n, and darkest across the breast. The fire head is greyish, leaving a contrasted dark bar from the bill through the eye, bounded below by the lighter throat

Fathertically, the Martin is a joy forever. Its deep throat gurgles and soft warblings fall pleasantly upon the ear. L'nlike those pests the Crackles its voice is never racous or harsh, nor has it the egg-stealing proclivities of those clownish rascals. Mi-'sided people will occasionally be found who object to having their morning's rest broken even by Martins. Doubtless such folk would object to being awakened by a symphony orchestra. They should be pitied rither hall blanıd; but, in either event, lisregarded. To my mind the soft morning choriss of the Martins is soothing and doc's not disturb rest: but is conducive 10 a luxurious semi-consciousness or borderlind to sleep that permits the enjoyment of slumber without awakening.

Martins are companionable. They live logether in colonies, visit ewch other's house? erping establishments, and chatter together continually. The new comer is greeted pleasantly and the departing guest sent on his way with good wishes and merry quips. Visitors from other colonies are received and permitted to peer in and examine the growing fanilics with the expressed satisfaction and approval of all concerned. The grealest good nature prevails. llough passing differences of opinion may occasion ally occur and he argued lowdly and vigorously, they ate tase and do not interfere with the general har aseny of the colony. It is only when strangers of other species untrude that all unite to eject them. Tha Hons. Sparrow is on its best behaviour on the premises and even the family cat walks with circunspeclion. retreating hastily if not gracefully to the meareat cower at the first assault of the angry birds. In fact such open rough and lumble warfare and tumult is not to the cal's liking and it usually prefers a consderable delour to crossing the open under a thriving Martıı colony.

Mattuns have a strong love of hone, and certainly develop it sense of proprielorship, almost human, in the house they are accustomed to occupy. The cccupalion of a new house already in the possession of Sparrows or other hirds, is seldom insisted upon. but on return in the spring to an ancestral home, intruders are positively and rudely ejected. Sparrows, being already on the ground and choosing the most desirable locations before most migrants arrive, often succeed in fighting off other more desirable tenants or even jumping the claims after they have been established by legal posscssion and lahour, but the Purple Martins are a match for sparrow nearly every time, though, like law-abidir $g$ citizens, they rarely lay claim to more than th:y have legal title 10. Another point of interesi in regard to Matlins and their attachment is thrir home. is the fact that they return to it after its use as a nursery is past. Other birds, probably all other Canadian birds, evince no interest in a nest after the young have left it, at least until a new nesting season recalls it to use. With them the nest is not a home or a shelter, but merely a receptacle for holding eggs and young, useless and without interest when that use is accomplished. Martins, however, relain possession until they gather for the fall migration, and the old homestead remains the family meeting place unlil the time of departure conies. After the middle of August, though through the day the Marlin house nay stand empty and silent, towards evening the whole joyous colony regather about the home of their late infancy and family associations. They clatter, g'urgle, and exchange family jokes and affeclionate greetings until, as the sun goes down, they crowd into the cubbyholes and the worder is where so many fully grown birds find room. Their voices grow softer and night and silence steals over all. As daylight comes, awakenIng chirps are heard, heads appear at the doors, birds emerge, and from the topmost points of the house they roll a vocal welcome to the day. Soon all are displaying themselves to the morning sun, preening and fluffing to let the grateful warmih sink 
into the base of thest plumage. As the sun gets higler they make short flights here and there, amıdst a rhorme of halpy bubbling song. By the lime the office man is belaking himself to his duily grind, the Martins bethink theusselves of their serious dulıes of life, and hie away for the day, over marshland and ocadow, field and stream, hr'letops or country, until evening again calls the'm logether. Such are some of the allractions of Purple Martins and the tale is not nearly exliausted.

Purple Martins are the only birds we have that will occupy a nesling box in colony. Other birds that can be induced to come to artificial test receptacles are solitary in their breeding habits and impatient of close neighbours even when of their own species. Hence it is useless to build bird licuses of inore than une compartment for other species than Martins. The rooms should be about six inches square and about the same height. A little more or less either way will not malter, but these sizcs should be approxinated. The rooms should be entirely separate from each other and not intercommunical. ing. They should be light, be draught and weather. light and have only a single entrance cach, which may be either round or square, one and three-quarters of an inch and abcut one or one and a half inches up from the floor. This last is important. A perch or shelf, outside, on the level with the enirance, is objcctionable as the young come out on it before they can $f y$, and the nalural crowding for prsition is certain to precipitate some to the ground. Such occurrences cause great disturbance and anxicty to the whole colony, but I do not think that the unfortunate viclin. of the accident is ever fed or raised, even if the commotion does not attract the watchful cat. A perch somewhat below the door, wide enough to comfortably hold one or more grown birds, is dcsirable, as Marlins love to sil about, and the inore perches and shelves there are for this purpose, the better they seem to like it and the more altraclive the colony is both from their viewpoin: and ours. The doors should be sheltered as much as possible by over-hanging eaves and porches. Driving rain beating into the nests of young birds is a dcadly eneny and, probably on this account, the best shelered entrances are most in demand. In the house in the frontispiece the two upp floors are always most in demand. Consequently, since $t / 3$. picture was taken, additional porch shelters havc been placed over the lower entrances and it is expected that thesc will make them more popular. The whole house should be covered with a good, light, weatherproof roof. Dampness means cold and that is death to young birds. It is also nost advisable to arrange the house to open so that after the birds have left for the winter the rooms can be thoroughly cleaned out. During lle infancy of the young, a certain amount of house cle ining is altendird 11, hut later the birds have no lime for such drudgery, and the debris from a couple of sason's occupancy will leave litle room within. 'Thr house should be erecled in the open, away from trees, or at least as ligh as the lop of closely adjoining buildings. Ordinarily it slould be from fourteen to Iwenty feet from the ground, depending on surrousdings. high enough to allow free flight and mancuvering room about it.

The materials of which the Martin or any other bird housc can be made olay be varied to suit taste or opportunity, lighiness, however, is desirable, especially in a large loouse or in one that has to be supprorted on a long unbraced pole, in the open. in wind and storm. I.ight pine, 'N or ${ }^{1} 2$ inch thick is usually sufficient. For paint, it should preferably $b_{\text {: }}$ dressed, but rough stuff takes stain tetter and is more i: general kerping. The house in the frontispiece was built of beaver-board a heary rardboard on a wooden frame and the roof and 6.:posed surfaces covered with colton well painted down. It has been up two sease ns now and shows no signs of deterioration that a brush-full of paint will not remedy. Probably a better material is the light wood of which orange crates are made. It would probably be well to give the house a good coat of black paint inside to prevent the light from glowing througlt it. "The support is a built-up box pole hollow in the centre and $s+t$ on a concrete base, as shown in the details accompanying. The heuse i.self slides up and down the pole on counter weighlid cords running over common sash pulleys in the top of the pole, with a heavy window weight inside. A bag of sand would do as well for the latler. This allows the house to be easily lowered to remove trapped sparrows or to be cleaned. Access is gained to the weight box inside through a removable section $n+$ ar the base.

These are about all the rules necessary for the erection of a successful Ma..in house. It may have as many rooms as desired, the more the merrier, and the larger the colony may grow, but there should at least be several; for Martins are sociable and love the company of their kind. Bearing in mind these requirements and the principles of good laste previously mentioned, there are no reasons why a Martin house that will be a constant source of pleasure to the neighbourhocd may not be built by almost anyone, After such a house is cnce erceled, about ail that can be done is to awail its occupation and meanwhile keep the sparrows out. They will invariably occupy it if not prevented. One good way to exclude them is to arrange enirances that can be easily closed from below. Shou'd sparrows 


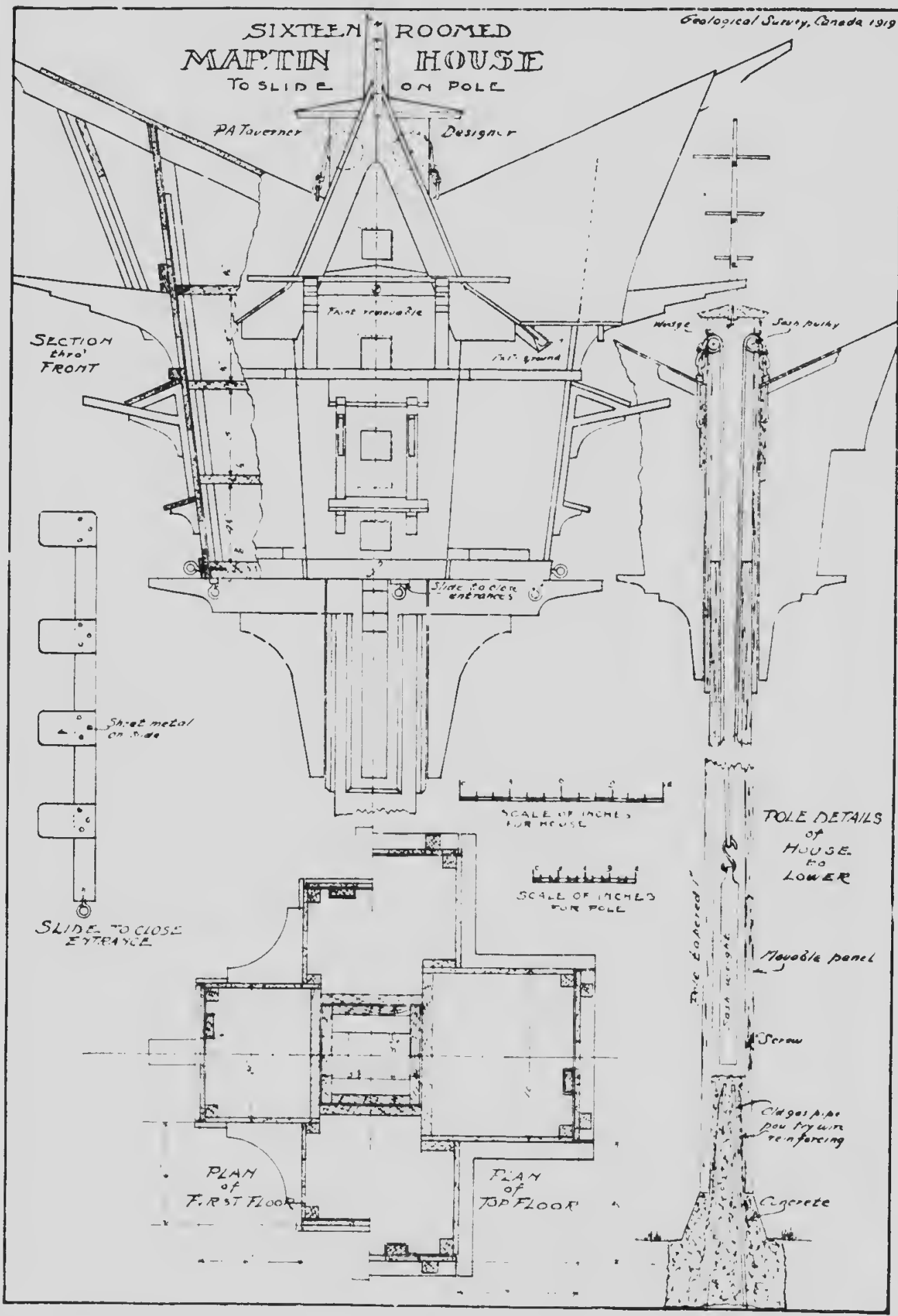


then $\mathrm{gct}$ in the door can be closed and the entrapped occupants destroyed. It is said that sparrows so caught can be rcleased again after a period of confinement and that the housc is a trap to them thercafter, and thei: fear of it will be communicated to their companions. Though this may be Iruc, for it is not out of keeping with the intelligence of our rowdy sparrows, who al times show an almost uncanny ability to take care of them. sclves, I will not personally vouch for it. A dead sparrow makes no nests, of that I am assured and I procced accordingly. Where it can be used, a .22 rifle with shot carlridges is the most satisfactory sparrow eradicator. Its range is short and its finc shot harmless at very limitcd distances. In the hands of a man of ordinary intelligence it is to be highly recommended. Sparrows, however, soon grow very wary, prccipitately retreating at sight of a man with a gun in the distanee, only to relurn to hurl derision, from the bird house ps-1 or entrance, at their bafflcd enemy. In such a case a sel gun discharged from ambush is very effectivc. A couple of siakes driven into the ground within range of the perch usually occupicd, nails for barrel and trigger-guard from which to hang the gun aimed at the spot, and a long string to the trigger passing through screweyes to an ambush, form an enci? of destruction that will effectivcly discourage the wariest and most persistent of sparrows. It is of proved cffecliveness against that last pair that continue to bafflc morc open methods.

If fortunc smiles Martins may come the first spring, but if she is fickle it may not be until the sccond or even the thild scason. It was the thild season before the writer gol Martins in his house and then only a single pair came. What appeared to be it lonely fenale arrived first. The place seemed to appeal to her and she tried to induce friends to come with her. She would sit on the gable end and call vainly to them. Then, somchow, she succeeded in bringing a committee of investigation back with her. They swarmed all over the house, into all rooms, talking and criticizing and making comparisons. I gathered that one did not like the plumbing, some objected to the decorations, and others to the view. in fact none secmed satisfied enough to move in and after emphalic expressions of opinion all left; $1 / 4$. single would-be tenant loudly prolestıng and vociferously ealling them back. When she saw that they werc actually deserting her off she flew after them and eventually brought them back for a fruitless reconsideration. Later she was jeincd by a mat." a juvenile or last year's male similar to herself in plumage and they scttled down to home-making by themselves. Through the brooding season friends from olher colonies eame and visited and it was no uncommon sight to sec ten or a dozen Martins laking an actıve and personai interest in th: growing family, and when the young came out sometimes as many as iwenty birds circled about the house. The nexi spring five or six pairs were in possession and the colony's welfare was established and has increased until, last summer, about twelve compartments werc occupied.

As a rule, cxecpt where neighbouring colonies are broken up and made homeless, newly crected houscs arc filled by the ovcrflow from neighbouring ones. Martins are conservative and probably as long as they can find salisfactory quarters in their ancestral mansion arc loath to move to strange surroundings. The beginning of new colonies, therefore, depends upon the number of housc-hunling birds in the neighbourhood.

\section{SINGLE ROOM HOUSES.}

In the following table the birds that can usually be induced to occupy ncsting boxes are listed and a schedule is given of their specific requirements. Various ideas as to the forms that may be adopted to fulfil these requirements can be obtained from the aecompanying plates.

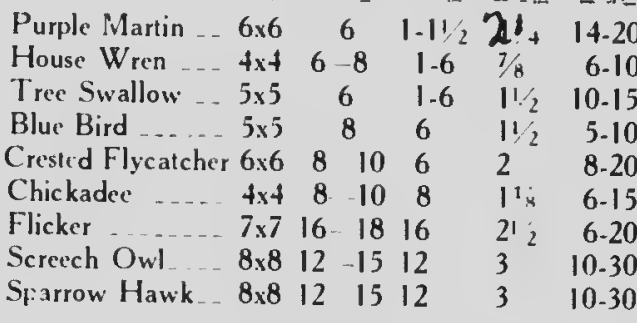

HOUSE. WREN.

The bird nost casily attracted to a bird house is the House Wren. Its tastes are so eatholic as to raise the suspicion that it has no taste at all, or that it is so busy with other people's business that it is unmindful of its own. Anything that has an entrance and is hollow, that it considers safe from cals, and that $c$ an be filled with sticks, is taken on occasion an old boot nailed up, a tin can, or even the pocket in an old coat have been repcatedly used. It is the only bird house that can be easily guarded from sparrows, for a snall entrance ${ }^{7} H$-ineh in diameter will serve the wren and keep pests out.

The House Wren is a busy mite and the wonder is that so small a body can contain such an amount of nervous energy. It may contain but it cannot hold it long. for every few moments it scems to 


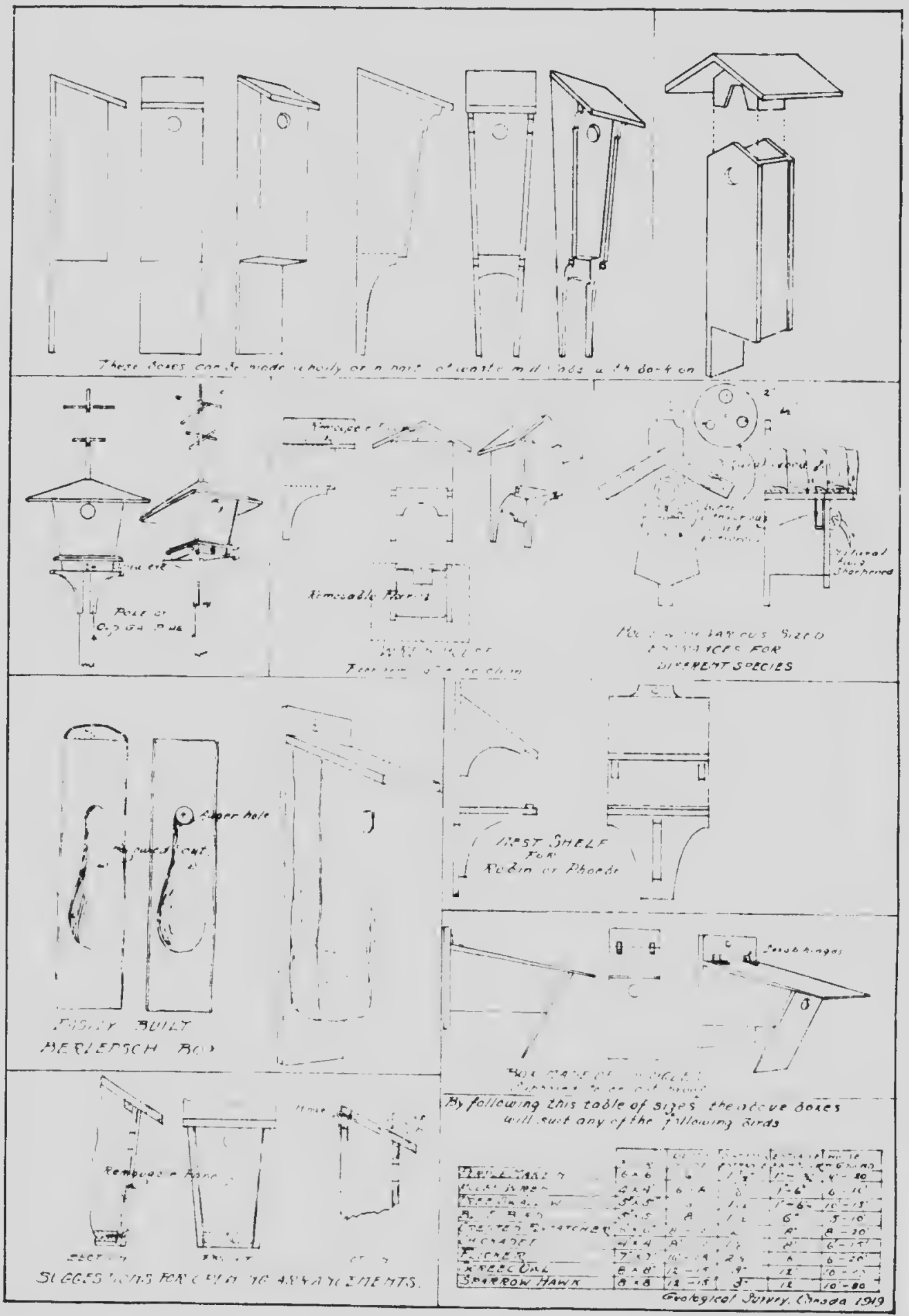


bcil over with bubbling song with notes falling over cach oilier in an atteinpt to get all out at once. It is a prying little busybody and not a nook or corner escapes its small inquisitive cycs and very littlc in the insect line its sharp, delicately tapered bill. Through the currant bushes it climbs and pecrs under evcry leaf, along every twig, then into the raspberry patch, down through the trellis and into the dark recesses of the phlox and larkspurs. The fence next receivcs its attention and cvery crack and joint is cxamincd. Pcrpendiculars and horizontals, right side up and upside down arc all one 10 it, gathering a worm here, a catcrpillar there and spiders cvcrywhere; and as it goes it scalters its bubbling song all over the garden. A fluttcrbudget and a Paul Pry, a busybody and a scold, but withal an important ally of the gaid 'ncr.

I wish this were all I could say of it, but candor makes me issuc a notc of warning. If there are other small birds nesting near-by, watch the Wren closely. It is also a scrious mischicf-makcr. This may be a trait of individuals, as there are rascals in all stations and walks of life. I hope it is, for Wrens have bcen known on morc than one occasicn to steal into the nests of other birds and puncturc the eggs therc. They do not eat the eggs, but scem to destroy the out of pure gnomish maliciousness. One is in a quandary whether to admire the littlc indefatigablc catcrpillar destroyer and merry songster or to wagc war on it as a wanton destroyer and an cnemy to husbandry.

\section{TREE SWALLOW.}

The Tree Swallow is dressed in a panoply of gleaming steel and white. All above is iridescent black with snowy white bclow. The female is similar, but with colours less pure and glcaming. Normally the Trce Swallow nests in old woodpeckcr-holes, in dead trccs, preferably overhanging water, but always in the open. Its sweet little "chinte a chinl", like watcr dripping into a quiet pool, is a pleasant sound and the glcam of its wings in the bright sun adds a most attractive prescnce to the garden. It has no bad faults that I have discovered and the number of insects it takcs is considerable. The house shculd be cn a pole in the open and from ten to fiftecn feet up, though greater hcights are not nccessarily cbjected to and the box can often be set up from the house lop if no more intimate situaticn is available.

\section{BLUEBIRD.}

John Burreuglis has described the Bluebird (the castern specics) as "The sky above and the carth beneath", and the discription fits it pcriectly. All above is iridescent cerulean blue and the throat, brcast and most below dull cartlyy red -"the goud red earth". It is another bird above reproach and the brilliant coat of the male, its matc's more subdued colours, its pensive notes, "purity, purity," and i's mcdest liquid warble are additions to any landscape. Its ncst requircments dre quite similar to these of the Trec Swallow, cxcept that it docs not ncst as high, often occupying holes in old fence posts not five feet from the ground and it is not spccially partial to the vicinity of watcr. I advise every one to get a Blucbird to nest in the garden whenever possible. I have not succecded in doing this yct, but in the less urban situations it should not be a difficult specics to entice.

\section{CRESTED FLYCATCHER.}

About the size of a sparrow but with a longer tail. Wood browns above with a slightly reddish tail, grcy throat and brcast, and palc lemon ycllow below; sexes alikc, combined with a number of peculiar but not inharmonious whistles, thesc are the characteristics of the Crested Flycatcher. It is not very often that it comes to nesting 'oxes, but the uncxpcctcd somelimes happens and the writer has had this bird in his garden for I wo ycars not conseculively. The first year of the Martin colony, when it consisted of only a single pair, Crcsted Flycatchers occupicd the wing of the house oppositc the Martins. Battles royal occurred constantly, but onc was as stubborn as the other and both remained. With a larger colony of Martins the Flycatchers wou!d have stood little chancc. The Flycatcher's box should be ten to twenty fect up and if it is partly shcltered by trees as on the cdge of a grove it will more closely approxinatc the natural habitat.

\section{FLICKER.}

The Flicker is a woodpecker and about as large as a robin. Valuable for itself it is still fi:rther useful as a provider of nesting holes for innumerable other birds. In fact the greater number of our hole-ncsling birds, unablc to excavatc for themselves, are largely depend nt upon holes made and abandoned by the Flicker. A Flicker box should closely approximatc the nest he makcs for himselfthe Berlepsch type hollowed out of a section of solid wood is the best. He is pcrfectly able to make his home for himsclf and is, therelore, not bound io accept such makcshifts as other specics arc sometimes forced to put up with. It will be noticed by referring to the drawings that the cavity is gourd or flask-shaped with a round bollom. This type is not difficult to makc. A section of natural trunk is first split and the two halves hollowed out with chisel and gouge to match and then firmly nailed togcther. A board on the top forms an cntrance shelter and prevents rain from draining down the joint. The ncst should be placed rather high, preferably facing outuard from the rdge of a trec or
trecs. 


\section{SCREECH OWL.}

The Screech Owl is not a common habitant of our gardens, but it is often found nesting in neglected orchards where hollow trees give opportunity. It is a small owl, not greatly exceeding a robin in size, but of appis ntly greater bulk on account of its heavicr busld and morc flutfy feathering. Its colour may be a finc pattern of either ash grey or burnt sienna red, with prominent ear tufts and yellow cycs. It is carnivorous of ccurse, and undoubtedly takes a certain number of snall birds, though mice form its principal farc. On the whole, it is much more a friend than an enemy of man. It may sound inconsistent to allow a bird of prey to build in the garden, much more to advocate building a nest box for it, but it is an altractive little fellow with many prctty ways. It is a gross libel to call it "screech" owl for whatever its song is it is not a screech, but a very pretty whistled trenolo, and as soothing a sound as can be imagincd. If one can be induced to stay within casy hearing distance from the house, its many other conversational themes will well repay the listener for his attention and will add an interest to the night that other bird voices give to the day. But if the owl interferes with other song birds? Wcll, it is mostly after mice and prefers them when it can get them; besides Martins, ard other birds that can be coaxcd into boxes, are probably safe inside when the owl is hunting. I would really hatc to have to choose between a Screceh Owl and the other birds-Martin colony exccpted of cours". Almost any one can have wrens and swallows in the garden, but the presenec of a Screech Owl gives a cachet of distinction that I $:$ ou!d hesitate to relinquish. To fall askep at night to the love making song of the Screech Owl, to be awakened in the morning by the pleasant gurgles of Purple Martins and pass the day to the songs of wrens and voices of Tree Swallows makes a modern comnınnplace garden approach in some degree at least $t$. from which we are supposed to have fallen.

\section{SPARROW HAWK.}

The Sparrow Hawk is hardly to be classed as an inhabitant of the garden. The smallest of our hawks, scarcely larger than a robin, and the brightest coloured of all our rapteres, the blue blood of the falcons runs through its vcins. Such a bird cannor be expected to confine itsclf to the formal restrictions of suburban life. Its home is the open fields, and there it combats grasshoppers and mice in true knightly fashion. Its chateau is in some high flung limb of a tall dead trec. As a nobleman of the old regime it cannot be expected to descend to the manual labour of the carpenter's and mason's trade, but inherits its residence from that useful commoner the Flicker, in whose abandoned or pre-empted stronghold it raises the cadets of its line. With all its nobility or perhaps because of it the Sparrow Hawk is still man's humble though often misjudged friend and it slays the grasshoppers and small mammal dragons of husbandry without let or stint. Though in the east there is probably little nced to ercct special quarters for it, as its natural habitat is still well supplied with suitable stubs, on the prairies of the west such accommodation is lacking, and it is often driven by necessity to occupy such prosaic sites as telegraph poles. Think how hard pressed a noble falcon must be to descend to such plebian usage; but noblesse oflige, and for the sake of the family line pride is swallowed. In such localities it is a sentimental and esthctic as well as an economic duty to provide this brave little fellow with facilities in kceping with his nceds and traditions. The Berlepsch house is the bcst type and it should be erected as high as possible, over or near what shrubbery is available. 


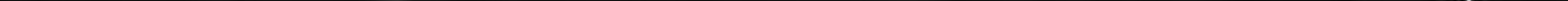

